\title{
THE IMPACT OF FOREST RESERVES ON LIVELIHOODS OF FRINGE COMMUNITIES IN GHANA
}

\author{
S. E. Edusah \\ Bureau of Integrated Rural Development (BIRD), \\ Kwame Nkrumah University of Science and Technology (KNUST), \\ Kumasi, Ghana
}

\begin{abstract}
This study looked at how the livelihoods of forest fringe communities have been affected by the constitution of four forest reserves in Brong Ahafo and Ashanti Regions of Ghana. The selection of the reserves for study was based on the fact that the reserves were surrounded by a number of relatively new and old settlements and have potential for socio-economic activities (agricultural production and ecotourism). Two main research approaches, structured questionnaire and semi-structured interviews were used in the data collection. A structured questionnaire together with open-ended questions was used to collect quantitative and qualitative information on household and community characteristics, including household incomes, farm sizes and tenancy arrangements. An open-ended questionnaire was designed for selected groups and community leaders to solicit their views and perceptions. The study found that farming was the main occupation of the people with cocoa and oil palm being the major cash crops grown in the area. Food crops grown include plantain, maize, cocoyam, cassava and rice. The major tenancy arrangements include family lands, outright purchase and sharecropping. Environmental problems in the area are decline in soil fertility, soil erosion, deforestation, bush fires and depletion of game and wildlife. Incomes were found to be low resulting in high poverty levels. The study shows that the communities have little role to play in the management of forest reserves.
\end{abstract}

Keywords: Forest reserves, fringe communities, livelihoods, sustainable management

\section{INTRODUCTION}

In recent times serious concerns have been raised about indiscriminate destruction of the tropical forest throughout the World. It is estimated that an average of 15.4 million hectares of tropical forests were destroyed between 1981 and 1990 (Laurance and Bierregaard 1997; Whitmore 1997). It is further argued that the annual total of forest conservation of 21 million hectares means that about 1.2 per cent of the world's tropical forest are being destroyed or degraded each year, especially in Amazonia, parts of South-East Asia and Africa (Whitmore 1997). For instance, at the beginning of the $20^{\text {th }}$ century the high forest zone in Ghana was estimated to cover over $82,000 \mathrm{~km}^{2}$ but this has been on the decline for many years, particularly since the 1970 s to about $18,726 \mathrm{~km}^{2}$ presently at a deforestation rate of 0.9 percent translating into about 5.2 million ha. of forest cleared an- 


\section{Edusah}

nually (BIRD, 1998). Drivers responsible for Ghana's diminishing forest include: population pressure; increasing demand for agricultural and forest products at local market and for export; over-capacity of forest industries; policy failures and weak institutions in the timber sector. There is therefore an urgent need to use forest resources in a sustainable way and this brings into focus the importance of forest reserves in Ghana. In order to prevent total destruction of Ghana's forest the colonial Governments constituted a number of forest reserves throughout the country and it is argued that the constitution of the reserves has had both positive and negative effects on the lives of the people. On one hand, it has made it possible for the country to preserve some of its forest resources and on the other hand, the constitution of the reserves has taken agricultural land from the forest fringe communities and this has had negative impact on the livelihood of the people. This study was therefore undertaken to assess the effect of the constitution of the forest on fringe communities of Bobiri, Bonkoni, Ayum and Subin Forest reserves. The study revealed that while as the forest reserves provide the fringe communities with some of their basic needs such as Non-Timber Forest Products (NTFPs), the reserves serve as hindrance to expansion in agricultural activities and this has had negative impact on the livelihood of the people.

\section{METHODOLOGY}

The two main research approaches, structured questionnaire and semi-structured interviews were used in the data collection. A structured questionnaire together with open-ended questions was used to collect quantitative and qualitative information on household and community characteristics, including household incomes, farm sizes and tenancy arrangements. An open-ended questionnaire was designed for selected groups and community leaders (Chiefs, Assemblymen and Unit Committee Members) to solicit their views and perceptions. Eighteen communities (60 per cent) out of 30 located within $10 \mathrm{~km}$ were purposively selected for the administration of the questionnaire (see Table 1). This was done in order to include settlements from different sides of the forest reserve and to achieve good geographical spread of settlements. A total of 150 respondents were then interviewed in each of the selected settlements. In addition to community questionnaire, institutional level data was collected from Forest Officers at Juaso and Goaso Forest District Offices and District Chief Executives (DCEs), the District Coordinating Directors (DCDs) and the Planning Officers of Asante Akim South District Assembly in the Ashanti Region and Asunafo North Municipal Assembly in the Brong Ahafo Region respectively using a structured interview checklist. A total of 8 officials were interviewed. Table 2 presents summary of the distribution of respondents. The data was first collected for a Tropenbos funded research and was up-dated in 2009 for the purpose of this paper.

Table 1: Settlements selected for the survey

\begin{tabular}{lll}
\hline Region & $\begin{array}{l}\text { Forest } \\
\text { Reserve }\end{array}$ & Communities \\
\hline Ashanti & Bobiri & Krofofrom \\
& & Kubease \\
& & Ndobom \\
& & New Koforidua \\
& & Krofomu \\
Brong Ahafo & Bonkoni & Mim \\
& & Nyame Bekyere \\
& & Asuadae \\
& Ayum & Ayomso \\
& & Kwakuduakrom \\
& & Kwawu \\
& & Asumura \\
& Subim & Anyinaye \\
& & Tipokrom \\
& & Adututukurom \\
& & Brekum \\
& & Gyasikrom \\
\hline
\end{tabular}

Source: Field Survey August 2009 
Impact of Forest Reserves on Livelihoods of Fringe Communities...

Table 2: Summary distribution of respondents

\begin{tabular}{|c|c|}
\hline Respondents & No. \\
\hline \multicolumn{2}{|l|}{$\begin{array}{l}\text { Community Level } \\
\text { 1. Opinion Leaders }\end{array}$} \\
\hline - Chiefs & 18 \\
\hline - Assembly-members & 4 \\
\hline - Unit Committee Members & 18 \\
\hline Others & 110 \\
\hline Total & 150 \\
\hline \multicolumn{2}{|l|}{ Institutional Level } \\
\hline 2. District Chief Executives & 2 \\
\hline $\begin{array}{l}\text { 3. District Coordinating Direc- } \\
\text { tors }\end{array}$ & $\begin{array}{l}2 \\
2\end{array}$ \\
\hline 4. Planning Officers & 2 \\
\hline Total & 8 \\
\hline
\end{tabular}

Source: Field Survey August 2009

\section{RESULTS AND DISCUSSIONS}

Forest Reserves: Constitution and Ownership

There are 46 Forest Districts in Ghana and they contain a total forest area of approximately $25,057.17 \mathrm{~km}^{2}$ (made up of approximately $18,000 \mathrm{~km}^{2}$ in the High Forest Zone and $7,000 \mathrm{~km}^{2}$ outside the High Forest Zone respectively). The reserve sites were carefully chosen and constituted throughout the country, although, the sizes of the reserves vary greatly. The major reserves in each of the 10 Regions are listed in Table 3

The study shows that three of the forest reserves - Bobiri, Bonkoni and Ayum - were constituted during the colonial era between 1934 and 1949 whilst the, Subim reserve, was constituted in 1956 shortly before independence (see Table 4). The Government of the day, in consultation with the Traditional Authorities, demarcated the area to be constituted into a reserve and after the necessary documentations the demarcated area was then enacted into a forest reserve with the interest vested in the government.

Ownership of the Forest Reserves

The study revealed that all the four forest reser- ves are situated on stool lands and therefore under the control of the Golden Stool of Ashanti. Under the customary usage, Ashanti stool lands are administered by various paramount stools on behalf of the Golden Stool. It was observed that the Bobiri Forest Reserve falls under the traditional jurisdiction of Juabeng and Effiduase Stools. The Bonkoni Forest Reserve is under the Akwaboa Stool while the Ayum and Subim Forest Reserves are under the Akwaboa and Hia Stools respectively. Traditionally, the lands are held in trust for the people and managed through a hierarchy of traditional rulers. In principle the Asantehene, who is the occupant of the Golden Stool, protects and manages all lands in Ashanti for the general good of the people. He is aided in his traditional role of land management by a number of paramount chiefs, divisional and sub-chiefs who represent him in various traditional areas, towns and villages in Ashanti.

Below the Golden Stool are the Paramount Stools, the Paramount Chief (Omanhene) is the head of the divisional and the sub-chiefs in his traditional area. He has jurisdiction over lands in his traditional area and answerable to the Asante King (Asantehene). Down the hierarchy of Traditional Authority are the divisional and sub-chiefs who live in forest fringe communities. The Divisional and Sub-Chiefs represent the Omanhene in towns and villages located close to the forest reserves. The chiefs who represent the Paramount stools in the fringe communities are the first contact persons on matters relating to the forest reserves. They indirectly help the District Offices of the Forestry Commission to protect the reserves. The results revealed that most of the communities were in existence before the constitution of the reserves and lost cultivable land in the process. It became clear during the study that the communities see the reserves as their property and partially cooperate in their protection. The government sees the communities as partners in the management of the reserves though until recently the attitude of the government has been exclusive and protectionist. 


\section{Edusah}

Table 3: Major forest reserves by regions.

\begin{tabular}{|c|c|c|}
\hline Region & Forest Reserve & Size $\mathrm{Km}^{2}$ \\
\hline Western & $\begin{array}{l}\text { Sukusuku } \\
\text { Subiri } \\
\text { Ankasa } \\
\text { Bia Tawya } \\
\text { Krokosua Hills }\end{array}$ & $\begin{array}{l}678.58 \\
587.93 \\
518.00 \\
481.74 \\
481.74\end{array}$ \\
\hline Ashanti & $\begin{array}{l}\text { Tano Offin } \\
\text { Asenanyo River } \\
\text { Afram Headwaters } \\
\text { Mankrang } \\
\text { Tinte Bepo (North, West, East) }\end{array}$ & $\begin{array}{l}402.23 \\
227.92 \\
201.24 \\
185.47 \\
115.51\end{array}$ \\
\hline $\begin{array}{l}\text { Brong } \\
\text { Ahafo }\end{array}$ & $\begin{array}{l}\text { Tain II } \\
\text { Aboniyere } \\
\text { Mpameso } \\
\text { Buru } \\
\text { Esukese } \\
\text { Subin }\end{array}$ & $\begin{array}{l}509.19 \\
411.18 \\
322.46 \\
302.25 \\
264.96 \\
238.28\end{array}$ \\
\hline Northern & $\begin{array}{l}\text { Yakombo } \\
\text { Kenikeni } \\
\text { Yereda } \\
\text { Nasia } \\
\text { Gambaga South West II }\end{array}$ & $\begin{array}{l}1,210.95 \\
515.98 \\
424.81 \\
314.69 \\
222.22\end{array}$ \\
\hline Central & $\begin{array}{l}\text { Kakum } \\
\text { Bonsa Ben } \\
\text { Assin Attandaso } \\
\text { Tonton } \\
\text { Bowiye }\end{array}$ & $\begin{array}{l}212.64 \\
155.40 \\
153.59 \\
146.34 \\
120.18\end{array}$ \\
\hline Eastern & $\begin{array}{l}\text { Atewa Range } \\
\text { Southern Scarp } \\
\text { Southern Scarp } \\
\text { Pra-Anum } \\
\text { Esukawkaw }\end{array}$ & $\begin{array}{l}232.32 \\
154.62 \\
146.75 \\
123.28 \\
122.25\end{array}$ \\
\hline Volta & $\begin{array}{l}\text { Chai River } \\
\text { Togo Plateau } \\
\text { Kabo River } \\
\text { Pra-Anum } \\
\text { Asuokoko River }\end{array}$ & $\begin{array}{l}182.36 \\
147.63 \\
135.98 \\
123.28 \\
116.03\end{array}$ \\
\hline $\begin{array}{l}\text { Upper } \\
\text { East }\end{array}$ & $\begin{array}{l}\text { Red Volta West } \\
\text { Red Volta } \\
\text { Tankwiddi East } \\
\text { Tankwiddi } \\
\text { Sissili Central }\end{array}$ & $\begin{array}{l}261.59 \\
217.60 \\
193.21 \\
193.21 \\
155.67\end{array}$ \\
\hline $\begin{array}{l}\text { Greater } \\
\text { Accra }\end{array}$ & Achimota & 3.60 \\
\hline
\end{tabular}

Source: Forestry Commission, Juaso and Goaso Forest District Offices 2009 
Impact of Forest Reserves on Livelihoods of Fringe Communities...

Table 4: Forest reserve and date of constitution

\begin{tabular}{lc}
\hline Forest Reserve & Date of Constitution \\
\hline Bobiri & 1949 \\
Bonkoni & 1934 \\
Ayum & 1940 \\
Subim & 1956 \\
\hline Source: Juaso and Goaso Forest & District Offices \\
2009 &
\end{tabular}

The study revealed that apart from the Traditional Authorities, there are a number of Governmental and public agencies involved in the management of forest reserves in Ghana performing different roles. For instance, the Ministry of Lands and Forests has the overall responsibility for sector planning, policy direction and for the monitoring of sectoral programmes designed to attain national forest goals. The Ministry is responsible for maintaining links with other ministries and agencies that have interest in the forest sector. Next to the Ministry is the Forestry Commission which was established in 1999 as a corporate body integrating the activities of all the public agencies that were previously individually responsible for the management and regulation of utilisation of forest and wildlife resources. At the Local Level the District Assemblies have a statutory responsibility to harness the human and natural resources for the development of the districts. They therefore have stake in the forest reserves situated in their areas of jurisdiction. The districts complement the efforts of the District Forestry Office to protect and manage the reserves and benefit directly from the revenues generated from the reserves.

\section{Forest Policy, Legislation and Institutions}

The study found that the 1994 Forestry and Wildlife policy statement is a major step towards striking a balance between competing demands for natural resources that are needed for the country's development and sustainable livelihoods of her people. The reality of the multiple objectives is reflected through the overall policy goal - conservation and sustainable development of the nation's forest and wildlife resources for maintenance of environmental quality and perpetual flow of optimum benefits to all segments of society. The results revealed that Forest and Wildlife policy recognises the rights of people to have access to natural resources for maintaining a basic standard of living and at the same time to live up to their responsibility to ensure the sustainable use of forest resources. From the Forestry Commission's point of view, the Government sees the forest fringe communities as key to pursuing sustainable forest management principles. For that reason the Government places emphasis on the concept of participatory forest management and protection of forest and wildlife resources and calls for the development of right strategies, modalities and programmes, in consultation with relevant agencies, rural communities and individuals. However, the study revealed that Forest fringe communities see current legislation as contradictory to wider government aims on the sustainable utilisation of the country's forest resources. The reasons being that the communities are in one hand seen as partners in protection of the forest but on the other hand the existing laws vest timber trees in the government with very little of revenue generated coming to the communities.

\section{Local Involvement in Forest Reserves Man- agement}

Traditionally, forests have been seen as valuable resources because they provide the people with some of the necessities of life such as timber and Non-Timber Forest Products (NTFPs). Although people in the study area substantially supplement their livelihoods and incomes with NTFPs they have no role in the forest reserve management. In spite of growing recognition that the wise and sustainable management of forest reserves requires the close involvement of all stakeholders, the study showed that the Forest Commission denies the local people access to the forest reserves and that the communities are not involved in forest management 


\section{Edusah}

regimes. Forest management regimes define the way in which a forest is used, which groups and individuals have access to it, the timing, means and degree of access, what is removed from the forest and the manner of its removal. Management regimes vary from state to communal ownership and control.

It was learnt from the study that the Forestry Department has not succeeded in stopping forest degradation. It has therefore become obvious that the Department cannot implement the management regime of the forest reserves single-handedly and without the involvement of the communities within and adjacent to the reserves, especially those whose livelihoods are forest-based. It is also true that because of user groups' dependence on the forests, alienating the communities from the natural resource base is certainly not the way to guarantee the future of the forests. With the near depletion of com- munal forests and increasing pressure on the forest reserves, a better management system has to be found to reduce degradation even further and guarantee the future of the existing forest reserve.

\section{Community involvement in reserve manage- ment}

The survey suggests very poor community involvement in the management of forest reserves in the study areas. The situation is pronounced in forest reserves in Brong Ahafo Region where respondents were unaware of who represents their communities on the management of the reserves (see Table 5). The non-involvement of fringe communities in the management of the reserve is an unacceptable omission that needs to be addressed by the government. This is because the communities are closer to the reserves and have better knowledge about the areas than anybody else.

Table 5: Community involvement in forest reserve management

\begin{tabular}{|c|c|c|c|c|}
\hline \multirow[t]{2}{*}{ Forest Reserve } & \multicolumn{4}{|c|}{ Community Representative on Forest Reserve Management } \\
\hline & Town/Village & Chief & Assembly member & Nobody \\
\hline \multirow[t]{5}{*}{ Bobiri } & Krofofrom & & * & \\
\hline & Kubease & $*$ & $*$ & \\
\hline & Ndobom & $*$ & & $*$ \\
\hline & New Koforidua & $*$ & & \\
\hline & Juabenma & & & $*$ \\
\hline \multirow[t]{3}{*}{ Ayum } & Mim & & & $*$ \\
\hline & Nyamebekyere & & & $*$ \\
\hline & Asuadae & & & $*$ \\
\hline \multirow[t]{3}{*}{ Bonkoni } & Ayomso & & & $*$ \\
\hline & Kwakuduakrom & & & $*$ \\
\hline & Kwawu & & & $*$ \\
\hline \multirow[t]{6}{*}{ Subim } & Asumura & & $*$ & \\
\hline & Anyimaye & & & $*$ \\
\hline & Tipokrom & & & $*$ \\
\hline & Baakodue & & & $*$ \\
\hline & Berekum & & & $*$ \\
\hline & Gyasikrom & & & $*$ \\
\hline
\end{tabular}

Source: Field Survey August 2009 


\section{Rights to forest reserves}

Table 6 shows that rights to forest reserves are greatly restricted. The majority of the respondents indicated that communities are not allowed to enter the reserves to undertake farming or some other commercial activities. To them, the reserves are restricted areas and one needs an authorisation from the District Forestry Officer to enter. It was observed that although entry is restricted, people enter the reserves illegally. For instance, hunters enter the forest under cover of darkness on hunting expeditions. There were also visible signs of collection of NTFPs such as palm-wine tapping, building materials and raffia. With increasing population of fringe communities the possibility of unsustainable pressures on NTFPs becomes real.

Forests have traditionally been used as valuable resources because they provide timber and NTFPs and in order to ensure regular supply prudent management of forest reserves is required. The wise and sustainable management of the valuable forest resources call for the close involvement of all stakeholders in the planning and management of the forests. However, there are concerns that local people are denied access to the forest reserves and do not benefit adequately from them. As a result illegal activities such as poaching pose great challenge to the management of the reserves. The survey therefore, assessed the right of forest fringe communities to NTFPs in the forest reserves.

The survey showed that people living in fringe communities in the study ares may harvest a variety of NTFPs so long as they respect the rules governing the reserve to the satisfaction of the District Forestry Officer. Table 7 shows that majority of the respondents (107) representing about 73.3 per cent, confirmed that they have access to NTFP from the reserves. It was however, learnt from the communities that people require permits to collect NTFP for commercial purposes but collection of NTFP for non-commercial purposes such as building materials requires no permit.

\section{Socio-Economic Characteristics of Fringe Communities}

The sections that follow discuss the socioeconomic characteristics of the forest fringe communities and take a closer look at the land tenure system in the study area, the household sizes, occupation, income level and living standards of the people.

Table 6: Right to forest reserves

\begin{tabular}{|c|c|c|c|c|c|c|}
\hline \multirow{2}{*}{$\begin{array}{l}\text { Forest } \\
\text { Reserve }\end{array}$} & \multicolumn{6}{|c|}{ Right to Forest Reserve } \\
\hline & \multicolumn{2}{|c|}{$\begin{array}{c}\text { Right to Forest } \\
\text { Reserve }\end{array}$} & \multicolumn{2}{|c|}{$\begin{array}{l}\text { No Right to Forest } \\
\text { Reserve }\end{array}$} & \multicolumn{2}{|c|}{ Total } \\
\hline Bobiri & $\begin{array}{l}\text { No. } \\
9\end{array}$ & $\begin{array}{r}\% \\
30.0\end{array}$ & $\begin{array}{l}\text { No. } \\
21\end{array}$ & $\begin{array}{c}\% \\
70.0\end{array}$ & $\begin{array}{c}\text { No. } \\
30\end{array}$ & $\begin{array}{c}\% \\
100\end{array}$ \\
\hline Ayum & 6 & 20.0 & 24 & 80.0 & 30 & 100 \\
\hline Bonkoni & 7 & 23.3 & 23 & 76.7 & 30 & 100 \\
\hline Subim & 11 & 19.6 & 45 & 80.4 & 56 & 100 \\
\hline Total & 33 & 22.6 & 113 & 77.4 & 146 & 100 \\
\hline
\end{tabular}

Source: Field Survey August 2009 
Table 7: Right of fringe communities to NTFP

\begin{tabular}{|c|c|c|c|c|c|c|}
\hline \multirow[t]{3}{*}{ Forest Type } & \multicolumn{6}{|c|}{ Right to NTFP } \\
\hline & \multicolumn{2}{|c|}{ Right to NTFP } & \multicolumn{2}{|c|}{ No Right to NTFP } & \multicolumn{2}{|c|}{ Total } \\
\hline & No. & $\%$ & No. & $\%$ & No. & $\%$ \\
\hline Bobiri & 28 & 93.3 & 2 & 6.7 & 30 & 100 \\
\hline Ayum & 20 & 66.7 & 10 & 33.3 & 30 & 100 \\
\hline Bonkoni & 20 & 66.7 & 10 & 33.3 & 30 & 100 \\
\hline Subim & 39 & 69.6 & 17 & 30.4 & 56 & 100 \\
\hline Total & 107 & 73.3 & 39 & 26.7 & 146 & 100 \\
\hline
\end{tabular}

Source: Field Survey August 2009

\section{Land tenure system}

There is a well-defined land tenure system in place in the study areas based on stool and family land ownership. The study shows that greater majority of the people have access to land. Two reasons account for this, first there are abundant agricultural lands in the area and second the traditional system of inheritance makes land available to majority of the indigenes. It was found that occupation of family lands and or allocation of land by family heads and share-cropping systems constitute the most important access routes to farmlands by indigenes and strangers or migrants in the surved villages. Families appropriate family lands as a right but strangers, regarded as non-indigenes, acquire specific usufruct rights through contractual agreement with landowners subject to payment of rent or depending on the abunu and abusa share-cropping systems-systems whereby the landowner takes one-third or half of the produce and the farmer retains two-thirds or half of the produce respectively, depending on the type of agreement entered into.

Although census data for migrant populations in the study communities were lacking, estimates by local people and personal observations indicated that the influx of migrant populations, as elsewhere in the southern forest zone have been increasing in recent times (Benneh 1988; Inkoom 1999). This has further increased the pressure on farmlands in the study area.

\section{Household sizes}

A household is used here to mean all the people living under one roof and eating from the same pot - comprising the man (invariably the head), his wife (or wives), children and other dependants. The survey revealed (see Table 8) that household sizes in the study area are large as compared to the average national figure of 6 people per household (Ghana Statistical Services 1996). The result depicts typical rural household sizes and was not unexpected. The large household sizes have serious implications for the future existence of the reserves. This is because as the younger members of the household grow older, the demand for farmland may increase and this may lead to agitation for release of portions of the reserves for farming activities.

Again, large households mean more mouths to feed and consequently an increased demand and harvest of NTFPs from the reserves. Experiences in developing countries indicate that large household size is associated with poverty and poverty is a catalyst for environmental degradation in rural areas. 
Table 8: Household sizes of forest fringe communities

\begin{tabular}{ccc}
\hline $\begin{array}{c}\text { Household } \\
\text { Size }\end{array}$ & No. & \% \\
\hline $1-3$ & 38 & 25.3 \\
$4-6$ & 56 & 37.3 \\
$7-9$ & 39 & 26.0 \\
$10+$ & 17 & 11.3 \\
Total & 150 & 100 \\
\hline
\end{tabular}

Source: Field Survey August 2009

\section{Occupation of fringe communities}

The main occupational characteristics of the friinge communities are presented in Table 9. The major occupation of most of the people is farming, which accounts for about 90.4 per cent of the total respondents. The abundant farmlands and favourable weather in the area account for the high percentage of farmers cultivating both cash and food crops in the fringe communities. Cocoa is the major cash crop although oil palm cultivation is gaining popularity among farmers who want to diversify their income base. Food crops including plantain, cocoyam, cassava and rice are extensively grown in the area. The average farm sizes are about 4 acres (1.6ha) for food crop farms and 15 acres (6ha) for cocoa farms and other cash crops. The average sizes of farms compare favourably with figures as found in most forest zones (Ghana Statistical Service, 1996).

The farming practices found in the area are still mainly the traditional system variously known as shifting cultivation, rotational bush fallow or slash and burn. Plantation mono-cropping of either cocoa or oil palm grown in association with food crops in the first 3 years and mixed food crop system are common practices among farmers. The productivity of shifting cultivation depends largely on the fertility of the soil, which is usually maintained by long fallow periods. Agricultural production in the study area is rain-fed consequently the fortunes of the farmer in any particular year are tied to the weather. Chambers (1981) has stated that seasonal cycles in rainfall and temperature gener- ate seasonal patterns of growth in crops and livestock and through them, cycles in labour requirement, input requirements, and availability of food and income. The seasonal cycle of agriculture has been poorly utilized by the people who engage in very little off-farm activities to earn extra income and this has helped to perpetuate poverty among the rural people.

Some of the problems associated with reduced fallow periods including deforestation, soil erosion and decline in soil fertility (Benneh and Agyapong 1990) have manifested themselves in the area and there is an added problem of the invasion of grass species, particularly siam weed (chromolaena odorata) in the fringe farms of the reserves. The grass species can facilitate the spread of bush fires in the area. For example, during the 1983 nation-wide bush and wild land fires triggered by drought, fires started from community farms and swept through the Bobiri Forest Reserve and parts of Ayum, Bonkoni and Subim Forest Reserves, causing considerable damage to trees and wildlife.

\section{Income levels and living standards}

Income levels in the study area are generally low (See Table 10). The average annual income of the respondents is about GHAË240.00 (US\$1=GH1.40) and this works out to be less than US\$1 a day using an exchange rate of GHAË1.40 to US $\$ 1$ and far below US $\$ 600$ per annum, an income below which one is described as poor. The Table shows that nearly half of the respondents have an annual income of GHAË100.00 or less. Respondents who have annual incomes of above GHAË500.00 constitute only $15 \%$. Income levels of the respondents are typical of rural economy where small-scale agriculture is the main livelihood. In these areas poverty is high as the result of low agricultural productivity and low prices of farm crops, particularly during the peak harvesting period. Given their location, there are few labour opportunities outside farming. Large household sizes and high dependency ratios have compounded the problem of poverty in 


\section{Edusah}

Table 9: Major occupation of respondents

\begin{tabular}{|c|c|c|c|c|c|c|c|c|c|c|c|c|c|c|}
\hline \multirow{3}{*}{$\begin{array}{l}\text { Forest } \\
\text { Reserve }\end{array}$} & \multicolumn{14}{|c|}{ Occupations } \\
\hline & \multicolumn{2}{|c|}{ Farming } & \multicolumn{2}{|c|}{$\begin{array}{l}\text { Civil Ser- } \\
\text { vant }\end{array}$} & \multicolumn{2}{|c|}{ Teacher } & \multicolumn{2}{|c|}{ Trader } & \multicolumn{2}{|c|}{$\begin{array}{l}\text { Chainsaw } \\
\text { Operator }\end{array}$} & \multicolumn{2}{|c|}{$\begin{array}{l}\text { Unem- } \\
\text { ployed }\end{array}$} & \multicolumn{2}{|c|}{ Total } \\
\hline & No. & $\%$ & No. & $\%$ & No. & $\%$ & No. & $\%$ & No. & $\%$ & No. & $\%$ & No. & $\%$ \\
\hline Bobiri & 21 & 70 & 4 & $\begin{array}{l}13 . \\
3\end{array}$ & - & - & 2 & 6.7 & 2 & 6.7 & 1 & 3.3 & 30 & 100 \\
\hline Ayum & 30 & 100 & - & - & - & - & - & - & - & - & - & - & 30 & 100 \\
\hline Bonkoni & 29 & 96.7 & 1 & 3.3 & - & - & - & - & - & - & - & - & 30 & 100 \\
\hline Subim & 52 & 92.9 & 1 & 1.8 & 1 & 1.8 & & - & - & - & - & - & 56 & 100 \\
\hline Total & 132 & 90.4 & 6 & 4.1 & 1 & 0.7 & 2 & 1.4 & 2 & 1.4 & 1 & 0.7 & 146 & 100 \\
\hline
\end{tabular}

Source: Field Survey August 2009

the fringe communities. The low income of the people is attributed to the effect of the forest reserves. It was explained that farmers are unable to expand their farms more so the communities have been forced to abandon their shifting cultivation practices. It was also revealed that fallow periods have reduced drastically from between 5 to 10 years to about 2 to 4years. It should be noted that decreasing fallow period is not peculiar to the study area but affects many parts of the world. The situation is particularly serious in Asia and the Pacific because most good agricultural lands have already been opened up. For instance in South Asia, the land in use per person fell from 0.17 hectares in 1990 to some 0.12 hectares in 2010 and in Latin America land in use per person was 0.44 hectares in 1990 and this is expected to decrease to about 0.35 hectares in 2010 (FAO, 1994).

\section{Ecotourism}

Typical of tropical rain forest, all the study sites hold fascinating features that could be developed into ecotourism. These include different timber spices, twigs and insects, numerous birds and butterflies and tranquil atmosphere of the forest. However, the study revealed that of the four reserves the Bobiri Forest Reserve has the greatest ecotourism potential because of its proximity to Kumasi, the cultural hub of Ghana. Importantly, Bobiri Forest Reserve is a sanctuary to about 500 different butterfly species. It became clear that if the tourism potentials of the reserves are properly packaged with the fringe communities in mind, it would bring tremendous improvement in the livelihoods of the people in the fringe communities (see for example Mieczkowski (1995)).

Table 10: Income levels of respondents

\begin{tabular}{lcc}
\hline $\begin{array}{l}\text { Income in } \\
\text { Ghana Cedis }\end{array}$ & No. & \% \\
\hline$<50.00$ & 37 & 24.7 \\
$51.00-100.00$ & 31 & 20.7 \\
$101.00-500.00$ & 55 & 36.7 \\
$501.00>$ & 21 & 14.7 \\
Unavailable & 6 & 4.0 \\
Total & 150 & 100 \\
\hline
\end{tabular}

Source: Field Survey August 2009

Note: $\$ 1=$ GHA $\ddot{E} 1.40$ 


\section{Infrastructure facilities}

Successive governments have been grappling with the provision of infrastructural facilities in rural areas of the country with little success and the situation in the forest fringe communities is compounded by poor accessibility, small sizes and the disperse nature of the fringe communities. These factors make provision of social amenities expensive and uneconomical. It was therefore of little surprise to observe that most fringe communities lack basic amenities such as good roads, electricity, health and water supply facilities among others. However Mim, which is the largest forest fringe community in the study area, has comparatively betterdeveloped infrastructural facilities. This is due to the presence of some timber companies in the town, which have over the years invested substantial amount of money in the development of basic facilities and services in the town. The presence of the companies has also attracted other social services such as health centre, rural banks and expanded commercial activities. Again the timber industry offer limited employment to people in the town.

Infrastructure facilities common to most communities in the study area include Primary and Junior Secondary Schools (JSSs), bore holes and traditional pit latrines. Although these basic amenities and others are in place, the communities complained that they do not adequately meet their needs and aspirations. The poor infrastructural facilities in the area, particularly poor roads, are major contributing factors accounting for low income levels and poor living standards of the people in the fringe communities. This is because the people find it difficult to transport their farm products to marketing centres.

\section{Deforestation and degradation}

The major form of local people's interaction with their natural environment is through agriculture and collection of NTFPs. Therefore, any changes in the local landscape are brought about by changes in the farming systems. The people face the twin problems of deforestation and degradation with their concomitant problems of decline in soil fertility, soil erosion, bush fires and depletion of game and wildlife.

It was observed that the growing interest in commercial production of food crops is having a deleterious effect on the local environment. For example, production of maize, cassava and plantain for the market has increased pressure on arable land. This has led to shortened fallow periods. The consequences of this have been declining soil fertility and low yields. Commercialisation of these crops and their activities, especially the use of fire during land preparation, has contributed significantly to the incidence of fires in off reserve land and there is the occasional risk of fires spreading into the forest reserves.

\section{Perceptions of Fringe Communities}

The perceptions of fringe communities are diverse and these perceptions affect their attitude towards forest reserves. This is because forest reserves are strongly linked to the economic, cultural and the environment of the people. This can be seen in four crucial areas:

i. forests have an impact on rural women and men by providing products which satisfy basic needs of the family;

ii. forests affect the economic lives of rural peoples by providing income and jobs;

iii. forests play an important role in local traditional religions, beliefs and practices; and

iv. forests have an important role in protecting and enriching the natural environment.

The ways forests perform these functions for the local people may be different, depending, for example, on the person's occupation, educational level, age, and religion. Additionally, some differences are largely gender specific. The study revealed for example that, a woman's first concern is to find enough forest products to satisfy the immediate family needs. On the other hand a man's first concern is for forest products that are primarily sources of cash such as cane, raffia and game. It was re- 


\section{Edusah}

vealed that, communities around forest reserves are faced with the economic impacts from a variety of ravaging wildlife species. The animals from the forest stray into adjacent farms and damage both food and cash crops (Oduro and Kwarteng 2001). Forest reserve management demands the cooperation of people living around them; without it, conflict over wildlife damage to crops and illegal use of resources from within the reserves are inevitable. It is for these reasons that the perceptions of communities have been assessed.

Table 11 summarises the perceptions of the people about forest reserves in the selected study areas. A greater percentage of respondents indicated that the constitution of the forest reserves was a good thing. They argued that the forests have great influence on the climate and ecosystem of the country and that reserves are store of food and medicine. They assert that rare forest species would be lost with the demise of the forest. Most respondents suggested that the boundaries of the forests should be guarded closely. However, a handful of them were not in favour of the continued existence of the reserves as presently constituted.

They argued that the reserves have deprived them of fertile farmlands and restricted agricultural productivity in the area. This perception is supported by local argument that some important economic resources, such as timber, from the forest are exploited by concessionaires who are outsiders to the detriment of the local economy.

\section{CONCLUSION}

This paper has looked at the effects of the constitution of forest reserves on the livelihoods of forest fringe communities. The study showed that the constitution of the forest reserves has both positive and negative effects on the livelihoods of the people. On the one hand the communities derive substantial part of their livelihoods from the forests by harvesting NTFPs but on the other hand the people are restricted by the forest reserves from expanding their
Table 11: Perception of respondents

\begin{tabular}{llclccc}
\hline $\begin{array}{l}\text { Forest } \\
\text { Reserve }\end{array}$ & \multicolumn{2}{l}{ Positive } & \multicolumn{2}{c}{ Negative } & \multicolumn{2}{c}{ Total } \\
& No. & $\%$ & No. & $\%$ & No. & $\%$ \\
\hline Bobiri & 27 & 90.0 & 3 & 10.0 & 29 & 100 \\
Ayum & 24 & 80.0 & 4 & 20.0 & 33 & 100 \\
Bonkoni & 26 & 86.7 & 4 & 13.3 & 48 & 100 \\
Subim & 44 & 78.6 & 12 & 21.4 & 73 & 100 \\
Total & 121 & 84.0 & 23 & 16.0 & 144 & 100 \\
\hline
\end{tabular}

Source: Field Survey August 2009.

farms although farming is the principal occupation of the fringe communities. Consequently, fallow periods have drastically been reduced resulting in poor crop yields and low incomes. Arguably the communities have positive perceptions of the forest reserves and support their protection however they play little or no role in their management. The study sites have the potential to develop into ecotourism sites which would impact positively on the livelihood of the people but that is not the priority for the management of the three forest reserves of Ayum, Bonkoni and Subim.

\section{ACKNOWLEDGEMENT}

This paper is based on an output from a research funded by the Tropenbos International, Ghana for which the author is grateful. The author also acknowledges the support of his research assistants at the Bureau of Integrated Rural Development (BIRD) at the Kwame Nkrumah University of Science and Technology, Kumasi Ghana.

\section{REFERENCES}

Benneh, G. (1988). The land Tenure and Agrarian System in the new Cocoa Frontier of Ghana: Wassa Akropong case study. In: Manshard, W. and W.B. Morgan (eds.), Agricultural Expansion and Pioneer Set tlements in the Humid Tropics. United Nations University. Tokyo: University Press. 
Benneh, G. and Agyapong, G. T. (1990). Land Degradation in Ghana. London: Commonwealth Secretariat, and Legon: Department of Geography and Resource Development., University of Ghana.

Bureau of Integrated Rural Development (BIRD) (1998). The Socio-Economic and Cultural Conditions Survey for the Study of the Reserve Forest management in Transitional Zone in Ghana. (Research report). Bureau of Integrated Rural Development, Kwame Nkrumah University of Science and technology, Kumasi.

Chambers, R. (1981). Rural Poverty Unperceived: Problems and Remedies, World Development, Elsevier, Amsterdam, 9(1):1-19.

FAO (1994) Land Degradation in South Asia: its severity, causes and effects upon the people, Rome.

Ghana Statistical Service, (1996). Ghana Living Standards Survey Reports on the Second Round (GLSS 2). Commercial Associates Limited, Accra.
Inkoom, D. K. B. (1999). Management of NonReserve Forests in Ghana: A Case Study of Mpohor Wassa East District. Spring Research Series, No. 24. Dortmund.

Laurance, W. F. and Bierregaard R. O. Jr. (1997) eds. Tropical Forest Remnants: Ecology, Management and Conservation of Fragmented Communities. University of Chicago Press Ltd, London.

Mieczkowski, Z. (1995). Environmental Issues of Tourism and Recreation. University Press of America, Inc. London.

Oduro, W. and Kwarteng, J. (2001). Correlates of Motivations of Game Rangers at the Mole National Park, Ghana. Journal of the University of Science and Technology Kumasi, . 20 (1, $2 \& 3): 31-40$.

Whitmore, T. C. (1997). Tropical forest disturbance, disappearance, and species loss, pp. 2-28. In: Laurence W.F. and Bierre gaard, Jr., R.O. (Editors), Tropical forest remnants. The University of Chicago Press, Chicago. 